\title{
Comparison of the Effectiveness of Greater Occipital Nerve Block in Patients Receiving and not Receiving Medical Prophylactic Treatment in Chronic Migraine
}

\author{
Kronik Migren Tedavisinde Medikal Profilaktik Tedavi Alan ve Almayan Hastalarda \\ Büyük Oksipital Sinir Blokaji Etkinliğinin Karşılaştırılması
}

๑ Meltem Karacan Gölen, (® Dilek Yılmaz Okuyan

Konya Numune Hospital, Clinic of Neurology, Konya, Turkey

\begin{abstract}
Objective: Chronic migraine (CM) refers to an increasing frequency of attacks and number of days with pain, and disease progression in patients with migraine. Recently, many studies have shown that peripheral nerve blockade is particularly effective in migraine, and greater occipital nerve (GON) blockade has been used in patients with treatment-resistant migraine. In our study, we aimed to investigate the effectiveness of the blockade performed in patients who were followed up with a diagnosis of migraine and underwent GON blockade due to persistent pain while receiving regular medical prophylaxis, and patients who only underwent GON blockade.

Materials and Methods: Sixty patients with CM aged 18-65 years who underwent medical treatment and GON blockade and 74 patients with CM who only underwent GON blockade were included in the study. The patients' visual analogue scale (VAS) and migraine disability assessment scale (MIDAS) scores, attack frequency, duration of attack, and need for analgesic use were recorded before the procedure, and in the first and third months. Then, the data in the pre-treatment period were compared with the data in the first and third months.

Results: In our both groups who received and did not receive prophylaxis and in whom recurrent GON blockades were applied, the duration of attacks, frequency of attacks and analgesic use significantly decreased, and a significant improvement was found in VAS and MIDAS scores in the $1^{\text {st }}$ and $3^{\text {rd }}$ months compared to the pre-treatment period $(\mathrm{p}<0.001)$. There was no statistically significant difference between the two groups in terms of pain duration, pain frequency, analgesic intake, and VAS and MIDAS scores.

Conclusion: The GON blockade is effective in patients with CM who cannot receive medical treatment or who have received medical treatment for a long time but have not had benefit. This method, which is easy to apply, has few adverse effects and has a high contribution to reducing treatment costs, can be considered as a treatment option for suitable patients.
\end{abstract}

Keywords: Headache, migraine, greater occipital nerve block

$\ddot{O} \mathbf{z}$

Amaç: Migrenli hastalarda atak sıklığının ve ağrılı gün sayısının artması ve hastalığın progrese olması kronik migren (KM) olarak adlandırılmaktadır. Son zamanlarda birçok çalışmada periferik sinir blokajının özellikle migrende etkin olduğu gösterilmiş ve büyük oksipital sinir [greater occipital nerve (GON)] blokajı tedaviye dirençli migren hastalarında kullanılmaya başlanmıştır. Çalışmamızda KM tanısı ile takipte olan ve düzenli medikal profilaksi almakta iken dirençli ağrıları nedeniyle GON blokajı uygulanan hastalar ile sadece GON blokajı uygulanan hastalarda blokajın etkinliğini araştırmayı amaçladık.

Gereç ve Yöntem: Çalışmaya 18-65 yaş arasında olan, medikal tedavi ve GON blokajı uygulanan 60 KM hastası ile sadece GON blokajı uygulanan 74 KM'li hasta dahil edildi. Hastaların vizuel analog skala (VAS) ve migren dizabilite değerlendirme ölçeği (MIDAS) skorları, atak sıklığı, atak süresi ve analjezik kullanım ihtiyacı işlem öncesinde, 1 . ayda ve 3 . ayda kayıt edilerek tedavi öncesi dönem ve 1 . ve 3 . ay verileri karşılaştırıldı.

Bulgular: Tekrarlayan GON blokajlarının uygulandığı hastalarımızda, profilaksi alan ve almayan her iki grupta 1 ve 3 . ayda, tedavi öncesi döneme göre atak süresi, atak sıklığı ve analjezik kullanımında azalma; VAS ve MIDAS skorlarında belirgin iyileşme saptandı (p<0,001). Her iki grup arasında ağrı süresi, ağrı sıklığı, analjezik alımı, VAS ve MIDAS skorları bakımından istatiksel olarak anlamlı fark saptanmadı.

Sonuç: Medikal tedavi alamayan veya uzun süre medikal tedavi almış ancak fayda görmemiş olan KM'li hastalarda GON blokajının etkin olduğu gözlenmiştir. Uygulanması kolay, yan etkisi oldukça az ve tedavi maliyetlerine katkısı yüksek olan bu yöntem uygun hastalarda tedavi seçeneği olarak düşünülebilir.

Anahtar Kelimeler: Baş ağrısı, migren, büyük oksipital sinir blokajı

Address for Correspondence/Yazışma Adresi: Meltem Karacan Gölen MD, Konya Numune Hospital, Clinic of Neurology, Konya, Turkey Phone: +90 3322354500 E-mail: drmeltemkaracan@hotmail.com ORCID: orcid.org/0000-0002-2422-9470

Received/Geliş Tarihi: 16.04.2021 Accepted/Kabul Tarihi: 13.12.2021

${ }^{\circ}$ Copyright 2022 by Turkish Neurological Society

Turkish Journal of Neurology published by Galenos Publishing House. 


\section{Introduction}

Migraine is a chronic neurological disease characterized by episodic headache attacks and accompanying symptoms, which is observed quite frequently in the population (1-3\%) (1). The increase in the frequency of attacks and the number of painful days in migraine patients is a harbinger of the progression of the disease and the process of becoming chronic. According to the latest classification of the International Headache Society (IHS); chronic migraine (CM) is defined as headache that occurs 15 days or more per month, of which at least 8 have migrainous characteristics or is responsive to migraine-specific treatment. In this definition, it is especially important to question and exclude drug overuse (2).

Benefiting from medical treatment in $\mathrm{CM}$ is very low, it is known that patients frequently use prophylactic drugs as well as intense analgesics, and patients experience disability and loss of work force due to pain. These chronic headaches also greatly affect daily life activities such as social life, physical and occupational performance (3).

Recently, many studies have shown that peripheral nerve blockade is effective in primary headaches, especially migraine $(4,5)$. In particular, greater occipital nerve (GON) blockade has been the most frequently preferred method of blockade in patients with $\mathrm{CM}(6,7)$. No similar study has been found in the literature evaluating the effectiveness of GON blockade with the migraine disability assesment scale (MIDAS) scale, and our study is the first in this respect.

In our study, the patients followed up due to CM who were on regular prophylaxis treatment and underwent GON blockade due to resistant pain, and the patients who did not receive medical prophylactic treatment and underwent GON blockade were evaluated in terms of the duration of pain, frequency of pain, analgesic intake, visual analog scale (VAS) score, and MIDAS score in the $1^{\text {st }}$ and $3^{\text {rd }}$ month follow-ups compared to the pre-treatment period.

\section{Materials and Methods}

Patients, aged between 18-65 years, who were were admitted to the neurology outpatient clinic between January 2018 and June 2020, and diagnosed as having CM according to the IHS classification, and who did not benefit from medical treatment and were resistant to treatment were included in the study. Sixty patients who received medical prophylaxis with GON blockade and 74 patients who received only GON blockade were recruited. The patients were receiving different types of prophylaxis treatment (propranolol $40-80 \mathrm{mg} /$ day, amitriptyline $10-25 \mathrm{mg} /$ day, duloxetine $60 \mathrm{mg} /$ day, venlafaxine $75-150 \mathrm{mg} /$ day, topiramate 50-100 mg/day). The patients who underwent GON blockade in the study were given detailed information about the procedure, and their consent was obtained and archived. The patients used analgesic, ergo and triptan derivatives for attack treatment when needed. Patients who received prophylaxis treatment continued to use beta-blockers, calcium channel blockers, antidepressant derivatives, antiepileptic treatments such as topiramate, and combination treatments. Exclusion criteria were headaches other than CM, acute pathology or space-occupying lesions on cranial imaging, pregnancy or breastfeeding, a history of malignancy, major psychiatric disorders, bleeding diathesis, receiving coumadin and derivative anticoagulant therapy, local anesthetic allergy, history of cervical or cranial surgery, neuromuscular dysfunction, and infection in the procedure area.

Sterilization conditions and emergency response conditions were provided for the patients. After the intervention area was cleaned with an antiseptic solution, $1.5 \mathrm{ml}$ of $2 \%$ lidocaine was applied bilaterally to $1 / 3$ medial of the imaginary line drawn between the protuberentia occipitalis externa and the mastoid process after palpating the occipital artery. When the needle reached the bone, it was retracted. It was injected after aspirating and checking that we were not in the artery (Figure 1). For supraorbital nerve (SON) blockade, the corrugator muscle was palpated and $1.5 \mathrm{ml}$ of $2 \%$ lidocaine was applied in the orbit of the pupil with a slight angle to prevent it from entering the foramens. A 26 Gauge (G) $13 \mathrm{~mm}$ needle was used for the application. The patient was followed up under observation for 30 minutes. The blockade procedure was applied bilaterally, once a week for the first month, 4 times, and once a month in the $2^{\text {nd }}$ and $3^{\text {rd }}$ months, for a total of 6 sessions. During the follow-up periods, the pain intensity values of 0 (no pain)-10 (worst pain) were questioned and VAS scores were recorded. MIDAS scores, frequency of attacks, duration of attacks and need for analgesic use were recorded at $1^{\text {st }}$ month and $3^{\text {rd }}$ month before the procedure. KTO Karatay University Faculty of Medicine Local Ethics Committee approval was obtained (2021/2345).

\section{Statistical Analysis}

The conformity of the data to the normal distribution was tested with the Shaphiro-Wilk test. The Mann-Whitney U test was used to compare the non-normally distributed variables between 2 groups, and the Freidman and Dunn multiple comparison tests were used to compare the data at different times. Relationships between categorical variables were tested with the chi-square test. SPSS for Windows version 24.0 program was used in the analysis and $\mathrm{p}<0.05$ was considered significant.

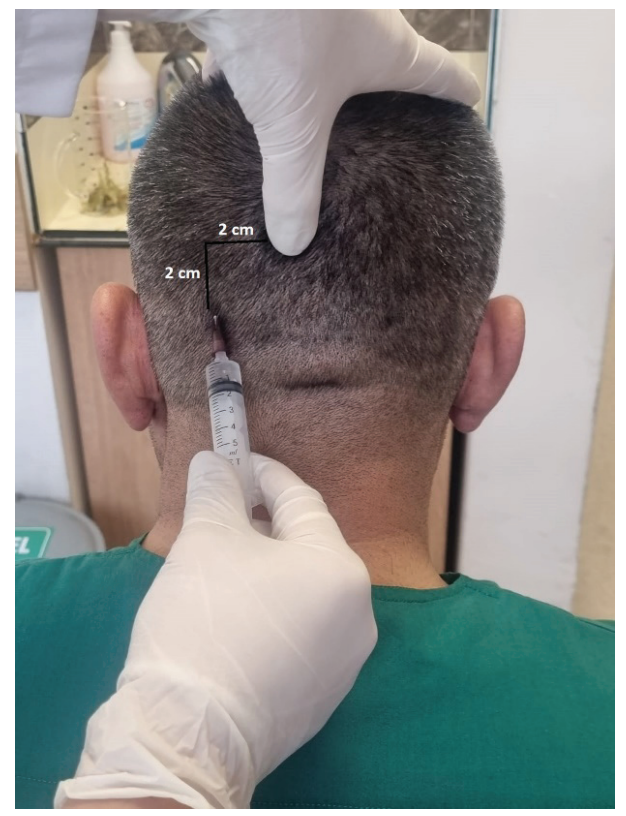

Figure 1. Technique of applying a greater occipital nerve blockade. Greater occipital nerve blockade; the point of entry is $2 \mathrm{~cm}$ lateral and 2 $\mathrm{cm}$ distal to the protuberantia oxpitalis 


\section{Results}

A total of 134 patients, 21 males and 113 females, were included in the study. Only blockade was applied to 74 patients, while blockade was applied to 60 patients under prophylactic treatment. The mean age of the patients was $42.29 \pm 6.18$ years. Pain duration before treatment was $20.86 \pm 15.18$ hours, frequency of pain was $17.32 \pm 2.92$ days/month, analgesic intake was $10.63 \pm 2.47$ per month, VAS score was $7.83 \pm 0.77$ and MIDAS score was $3.25 \pm 0.49$. In the $1^{\text {st }}$ month after the blockade treatment, the duration of pain was $9.45 \pm 6.47$ hours, the frequency of pain was $4.34 \pm 1.45$ days/ month, analgesic intake was $4.84 \pm 1.54$ per month, VAS score was $3.81 \pm 1.02$ and MIDAS score was $1.96 \pm 0.51$. In the $3^{\text {rd }}$ month follow-up of the patients, the duration of pain was determined as $3.8 \pm 2.27$ hours, the frequency of pain was $3.01 \pm 0.89$ days/ month, analgesic intake was $3.34 \pm 1.1$ per month, VAS score was $2.76 \pm 0.62$ and MIDAS score was $1.57 \pm 0.5$ (Table 1 ).

In Table 2, the parameters that were compared between the groups in which GON blockade was applied while under medical treatment and those in which only GON blockade was applied were given in detail. No significant difference was observed between the two groups in terms of age and gender. There was no statistically significant difference between the two groups in terms of pain duration, pain frequency, analgesic intake, VAS and

Table 1. Demographic data

\begin{tabular}{|c|c|c|c|}
\hline & & $\mathrm{n}$ & $\%$ \\
\hline Condo & $\mathbf{M}$ & 21 & 15.7 \\
\hline Gender & $\mathrm{F}$ & 113 & 84.3 \\
\hline D. & GON & 74 & 55.2 \\
\hline Prophylaxis & Prophylaxis + GON & 60 & 44.8 \\
\hline & & Mean \pm SD & $\begin{array}{l}\text { Median } \\
(\min -\max )\end{array}$ \\
\hline Age & & $42.29 \pm 6.18$ & $43(30-54)$ \\
\hline Duration (be & fore treatment) & $20.86 \pm 15.1$ & $15(6-72)$ \\
\hline Frequency $(b$ & efore treatment) & $17.32 \pm 2.92$ & $16(12-24)$ \\
\hline $\begin{array}{l}\text { Analgesic in } \\
\text { treatment) }\end{array}$ & ake (before & $10.63 \pm 2.47$ & $10(5-20)$ \\
\hline VAS (before & reatment) & $7.83 \pm 0.77$ & $8(6-9)$ \\
\hline MIDAS (befo & re treatment) & $3.25 \pm 0.49$ & $3(2-4)$ \\
\hline Duration $\left(1^{\mathrm{st}}\right.$ & month) & $9.45 \pm 6.47$ & $8(2-48)$ \\
\hline Frequency (1 & st month) & $4.34 \pm 1.45$ & $4(1-10)$ \\
\hline Analgesic in & ake ( $1^{\text {st }}$ month) & $4.84 \pm 1.54$ & $5(1-12)$ \\
\hline VAS $\left(1^{\text {st }}\right.$ mon & & $3.81 \pm 1.02$ & $4(1-5)$ \\
\hline $\operatorname{MIDAS}\left(1^{\text {st }} \mathrm{n}\right.$ & lonth) & $1.96 \pm 0.51$ & $2(1-3)$ \\
\hline Duration $\left(3^{\text {rc }}\right.$ & month) & $3.8 \pm 2.27$ & $4(1-12)$ \\
\hline Frequency $(3$ & ${ }^{\mathrm{rd}}$ month) & $3.01 \pm 0.89$ & $3(1-5)$ \\
\hline Analgesic in & ake ( $3^{\text {rd }}$ month $)$ & $3.34 \pm 1.1$ & $3(0-6)$ \\
\hline VAS $\left(3^{\text {rd }}\right.$ mor & th) & $2.76 \pm 0.62$ & $3(2-4)$ \\
\hline MIDAS $\left(3^{\text {rd }} r\right.$ & nonth) & $1.57 \pm 0.5$ & $2(1-2)$ \\
\hline
\end{tabular}

GON: Greater occipital nerve, VAS: Visual analogue scale, MIDAS: Migraine disability assesment scale, M: Male, F: Female, min: Minimum, max: Maximum, SD: Standard deviation
MIDAS scores. However, when each parameter was evaluated separately, a statistically significant difference was found in the $1^{\text {st }}$ and $3^{\text {rd }}$ months in pain duration, pain frequency, analgesic intake, VAS and MIDAS scores compared to the pre-treatment baseline values. In both groups, improvement in pain duration was observed in the $1^{\text {st }}$ and $3^{\text {rd }}$ months compared to the pretreatment period, which was statistically significant $(\mathrm{p}<0.001$ and $\mathrm{p}<0.001)$. The median pain frequency in the prophylaxis + GON group was 16 days/month before treatment, 4 days/month in the $1^{\text {st }}$ month, and 3 days/month in the $3^{\text {rd }}$ month, and the number of days with pain decreased, and the findings were statistically significant $(\mathrm{p}<0.001)$. While the median pain frequency was 16 days/month before treatment in the GON group, it was 4 days/ month in the $1^{\text {st }}$ month and 3 days/month in the $3^{\text {rd }}$ month. There was a statistically significant decrease in pain frequency $(\mathrm{p}<0.001)$. In the prophylaxis + GON group, the median analgesic intake was 10 units/month before the treatment, while it was 5 units/ month in the $1^{\text {st }}$ month and 3 units/month in the $3^{\text {rd }}$ month, and a statistically significant decrease was observed in the analgesic intake $(\mathrm{p}<0.001)$. In the GON group, the median analgesic intake was 10 per month before the treatment, 5 in the $1^{\text {st }}$ month and 3 in the $3^{\text {rd }}$ month, and a statistically significant decrease was found in the analgesic intake $(\mathrm{p}<0.001)$. A statistically significant decrease was found in the VAS score in the prophylaxis + GON group and the GON group compared to the pre-treatment period $(\mathrm{p}<0.001$ and $\mathrm{p}<0.001)$.

A statistically significant decrease was observed in the MIDAS score in the prophylaxis + GON group and the GON group compared to the pre-treatment period $(\mathrm{p}<0.001$ and $\mathrm{p}<0.001)$. Detailed data are given in Table 2.

\section{Discussion}

The GON blockade has recently become a frequently preferred method in primary headaches, especially in CM, and its effectiveness has been demonstrated in many studies $(8,9,10,11)$. In our study, we compared the frequency of attacks, duration of attacks, analgesic intake, VAS and MIDAS scores of patients who received only GON blockade and those who underwent GON blockade and received prophylaxis treatment. During the 3-month follow-up period, it was observed that recurrent GON blockades provided a significant improvement in VAS and MIDAS scores and a decrease in the duration of attacks, the frequency of attacks, and the use of analgesics compared to the pre-treatment period, similarly in both groups. This result suggested that the GON blockade was effective independent of medical treatment, and that the method could be preferred as a satisfactory option for patients who could not receive medical treatment.

In accordance with the study protocol, we applied GON blockade in repetitive sessions, once a week in the first month, (4 times in the first month, and consecutively) once in the $2^{\text {nd }}$ and $3^{\text {rd }}$ months. Similarly, there are many studies in the literature showing that repetitive blockade is effective. In our study, an improvement was detected in the pre-treatment parameters of the patients in the first month, and it was observed that this effect continued until the third month with a monthly reminder dose $(12,13)$. Ruiz Piñero et al. (14) applied repetitive blockade and observed that some of the patients responded after the third blockade, and therefore emphasized the importance of repetitive blockade. 
Table 2. Comparison of GON and prophylaxis + GON groups

\begin{tabular}{|c|c|c|c|}
\hline & $\begin{array}{l}\text { Prophylaxis + } \\
\text { GON }(n=60)\end{array}$ & GON $(n=74)$ & $\mathrm{p}$ \\
\hline & Mean \pm SD & Mean \pm SD & \\
\hline Age & $42.38 \pm 6.16$ & $42.22 \pm 6.24$ & 0.916 \\
\hline Gender & - & - & 0.847 \\
\hline M & $9(15)$ & $12(16.2)$ & - \\
\hline $\mathbf{F}$ & $51(85)$ & $62(83.8)$ & - \\
\hline- & $\begin{array}{l}\text { Prophylaxis + } \\
\text { GON }(n=60)\end{array}$ & $\begin{array}{l}\text { GON } \\
(n=74)\end{array}$ & - \\
\hline Variables & $\begin{array}{l}\text { Median } \\
(25 \%-75 \%)\end{array}$ & $\begin{array}{l}\text { Median } \\
(25 \%-75 \%)\end{array}$ & $\mathrm{p}$ \\
\hline Headache duration & (hour) & & \\
\hline Before treatment & $15(10-24)$ & $15(12-24)$ & 0.834 \\
\hline $1^{\text {st }}$ month & $8(6-10)$ & $8(6-10)$ & 0.763 \\
\hline $3^{\text {rd }}$ month & $3.5(2-6)$ & $4(2-6)$ & 0.909 \\
\hline- & $\mathrm{p}<0.001^{*}$ & $\mathrm{p}<0.001^{*}$ & - \\
\hline Headache frequen & $\mathrm{y}$ (day/month) & & \\
\hline Before treatment & $16(16-20)$ & $16(16-20)$ & 0.472 \\
\hline $1^{\text {st }}$ month & $4(3.5-5)$ & $4(3-5)$ & 0.516 \\
\hline $3^{\text {rd }}$ month & $3(2-4)$ & $3(2-4)$ & 0.890 \\
\hline- & $\mathrm{p}<0.001 *$ & $\mathrm{p}<0.001^{*}$ & - \\
\hline Analgesic intake & nit/month) & & \\
\hline Before treatment & $10(8-12)$ & $10(10-12)$ & 0.263 \\
\hline $1^{\text {st }}$ month & $5(4-5.5)$ & $5(4-6)$ & 0.631 \\
\hline $3^{\text {rd }}$ month & $3(3-4)$ & $3(3-4)$ & 0.826 \\
\hline- & $\mathrm{p}<0.001^{*}$ & $\mathrm{p}<0.001^{*}$ & - \\
\hline VAS & & & \\
\hline Before treatment & $8(7-8)$ & $8(7-8)$ & 0.254 \\
\hline $1^{\text {st }}$ month & $4(3-4)$ & $4(3-5)$ & $0.041^{*}$ \\
\hline $3^{\text {rd }}$ month & $3(2-3)$ & $3(2-3)$ & 0.996 \\
\hline- & $\mathrm{p}<0.001^{*}$ & $\mathrm{p}<0.001^{*}$ & - \\
\hline MIDAS & & & \\
\hline Before treatment & $3(3-4)$ & $3(3-4)$ & 0.984 \\
\hline $1^{\text {st }}$ month & $2(2-2)$ & $2(2-2)$ & 0.800 \\
\hline $3^{\text {rd }}$ month & $2(1-2)$ & $2(1-2)$ & 0.867 \\
\hline- & $\mathrm{p}<0.001^{*}$ & $\mathrm{p}<0.001^{*}$ & - \\
\hline
\end{tabular}

*Significant at the 0.05 level; Mann Whitney-U test was used for intergroup comparisons and Freidman test was used for in-group comparisons. GON: Greater occipital nerve, VAS: Visual analogue scale, MIDAS: Migraine disability assesment scale, M: Male, F: Female, SD: Standard deviation

Although there are many studies showing the effectiveness of GON blockade, a standardization has not yet been achieved in terms of the method and the frequency of drug dose administration. In this regard, the American Headache Society has reported application recommendations for GON blockades, but it has been notified that there is no consensus on the amount to be applied and the frequency of repetitions, due to the lack of randomized controlled studies (15). There is no consensus on the choice of local anesthetic agent or steroid combination used in GON blockade. Local anesthetics reversibly block sodium channels by acting on unmyelinated C-fibers, especially in sodium channels in nerve fibers, and cause depolarization in demyelinated C-fibers and myelinated fibers that play a role in the transmission of pain signals, thereby preventing the transport of pain signals (16). Dilli et al. (17) compared the efficacy of lidocaine, bupivacaine and methylprednisolone in patients with migraine and reported that they did not observe a significant difference between the groups in terms of the duration of migraine pain and analgesic consumption. Other studies comparing the effects of local anesthetics did not show superiority of local anesthetics over each other (18). Lidocaine was preferred to be used because it was easier to obtain in our hospital.

In the study of Inan et al. (7), in which they evaluated 25 migraine patients who received prophylaxis treatment and received GON blockade, and 53 patients who received only GON blockade, attack frequency, attack duration and pain severity were compared over a 3-month period, and it was reported that no statistically significant difference was observed in terms of the headache parameters between the two groups. It was suggested that GON blockade was effective even if medical prophylaxis was not added (7). Similarly, in our study, blockade was found to be effective in both groups regardless of prophylaxis treatment.

In studies evaluating the effectiveness of GON blockade in migraine patients, it was reported that the application reduced the frequency of attacks and the number of days with pain $(19,20)$. In our study, significant improvement in the number of days with pain and the frequency of attacks during the 3-month follow-up period compared to the pre-treatment period was noted in both groups. In a study conducted by Caputi and Firetto (5) using 10 sessions of $0.5-1 \mathrm{ml}$ bupivacaine $0.5 \%$, GON blockade and SON blockade were applied in $85 \%$ of the patient group for 6 months. A decrease in the duration, frequency and severity of headaches was detected compared to the pre-treatment period (5).

Another remarkable finding in our study was that the need for analgesics decreased significantly in both groups during the 3-month treatment compared to the pre-treatment period. In a study on this subject, it was reported that migraine patients with excessive use of triptan and analgesic derivatives responded to GON blockade and the need for analgesics decreased in the patients (9). Tepe and Tertemiz (21) compared the effectiveness of GON blockade and GON + SON blockade in patients with drug overuse. They stated that both methods decreased the analgesic need, number of days with pain, duration of pain, numeric rate scale scores of the patients, and they observed improvement in all parameters (21). In our study, we evaluated this decrease in the need for analgesics as the positive effect of GON blockade. This positive effect of GON blockade, which reduces the need for analgesics and chronic use of analgesics, has contributed to the reduction of treatment costs and systemic side effects that may occur due to chronic use of analgesic derivative drugs, since it provides a decrease in the need for analgesics as well as improving the daily life activities of the patients. For this reason, GON blockade is thought to be a preferred treatment option in migraine patients who can not take oral medication due to their systemic disease. In addition, it is clear that if it is preferred during the drug detoxification period when oral medication is discontinued in the 
patient group with drug overuse, it will contribute to compliance with the treatment as it will reduce the need for analgesics.

In our study, VAS scores improved in the $1^{\text {st }}$ and $3^{\text {rd }}$ months compared to the pre-treatment period. Similar to our study, previous studies showed that GON blockade improved VAS scores $(7,12)$. In the randomized controlled study of Gul et al. (6), patients underwent repeated GON blockade once a week in the first month and once in the following second and third months, and an improvement in the VAS score was observed in the GON blockade group, and this effect was observed to continue in the second and third months. Despite this, no positive effect was observed on VAS scores in the control group after the $1^{\text {st }}$ month.

The MIDAS scale, which evaluated daily living activities of migraine patients, was applied to our patients in order to evaluate the contribution of GON blockade to the daily living activities of individuals, unlike other studies. We observed improvement in the MIDAS scale in the $1^{\text {st }}$ and $3^{\text {rd }}$ months compared to the pretreatment period. No similar study was found in the literature in which the contribution of GON blockade to activities of daily living was evaluated using the MIDAS scale. In this respect, our study is the first of its kind.

\section{Study Limitations}

Side effects reported in the literature are very few, and it has been reported that tenderness at the application site, vaso-vagal syncope, and nausea are the most common $(9,22)$. In our study, no serious side effects were observed during and after the application. The limitations of this study were that our study group was small, we did not have a control group, and our follow-up period was short. In the future, prospective, randomized and placebocontrolled studies in larger groups are needed.

\section{Conclusion}

As a result, it was observed that GON blockade was effective even when applied alone in patients with $\mathrm{CM}$ who had limitations in their daily activities despite medical treatment and could not use medical treatment. The positive effect on the duration of pain, the number of painful days per month, and the severity of pain was pleasing. It is easy to apply, has very few side effects, and has positive effects such as reducing treatment costs. This method should be considered as a treatment option in suitable patients. Since CM is known to greatly affect social life, physical and occupational performance, if it is preferred in suitable patients, the contribution and improvement it will provide to daily life activities, and the reduction in acute and prophylactic drug need and burden will be a hope for migraine patients.

\section{Ethics}

Ethics Committee Approval: KTO Karatay University Faculty of Medicine Local Ethics Committee approval was obtained (2021/2345).

Informed Consent: Approval received.

Peer-review: Internally peer-reviewed.

\section{Authorship Contributions}

Surgical and Medical Practices: M.K.G., D.Y.O., Concept: M.K.G., D.Y.O., Design: M.K.G., D.Y.O., Data Collection or Processing: M.K.G., D.Y.O., Analysis or Interpretation: M.K.G., D.Y.O., Literature Search: M.K.G., Writing: M.K.G.

Conflict of Interest: No conflict of interest was declared by the authors.

Financial Disclosure: The authors declared that this study received no financial support.

\section{References}

1. Castillo J, Muñoz P, Guitera V, Pascual J. Kaplan Award 1998. Epidemiology of chronic daily headache in the general population. Headache 1999;39:190196.

2. Headache Classification Committee of the International Headache Society (IHS) The International Classification of Headache Disorders, 3rd edition. Cephalalgia 2018;38:1-211.

3. Blumenfeld AM, Varon SF, Wilcox TK, et al. Disability, HRQoL and resource use among chronic and episodic migraineurs: results from the International Burden of Migraine Study (IBMS). Cephalalgia 2011;31:301315 .

4. Inan LE, Inan N, Unal-Artık HA, Atac C, Babaoglu G. Greater occipital nerve block in migraine prophylaxis: Narrative review. Cephalalgia 2019;39:908-920.

5. Caputi CA, Firetto V. Therapeutic blockade of greater occipital and supraorbital nerves in migraine patients. Headache 1997;37:174-179.

6. Gul HL, Ozon AO, Karadas O, Koc G, Inan LE. The efficacy of greater occipital nerve blockade in chronic migraine: A placebo-controlled study. Acta Neurol Scand 2017;136:138-144.

7. Inan $\mathrm{N}$, Inan LE, Coşkun Ö, Tunç $\mathrm{T}$, Ilhan $\mathrm{M}$. Effectiveness of greater occipital nerve blocks in migraine prophylaxis. Noro Psikiyatr Ars 2016;53:45-48.

8. Ashkenazi A, Young WB. The effects of greater occipital nerve block and trigger point injection on brush allodynia and pain in migraine. Headache 2005; 45:350-354.

9. Afridi SK, Shields KG, Bhola R, Goadsby PJ. Greater occipital nerve injection in primary headache syndromes--prolonged effects from a single injection. Pain 2006;122:126-129.

10. Tobin JA, Flitman SS. Occipital nerve blocks: effect of symptomatic medication: overuse and headache type on failure rate. Headache 2009;49:1479-1485.

11. Weibelt S, Andress-Rothrock D, King W, Rothrock J. Suboccipital nerve blocks for suppression of chronic migraine: safety, efficacy, and predictors of outcome. Headache 2010;50:1041-1044.

12. Okmen K, Dagistan Y, Dagistan E, Kaplan N, Cancan E. Efficacy of the greater occipital nerve block in recurrent migraine type headaches. Neurol Neurochir Pol 2016;50:151-154.

13. Takmaz SA, Inan $\mathrm{N}$, Uçler $\mathrm{S}$, et al. Greater occipital nevre block in migraine headache: preliminary results of 10 patients. Agri 2008;20:47-50.

14. Ruiz Piñero M, Mulero Carrillo P, Pedraza Hueso MI, et al. Pericranial nerve blockade as a preventive treatment for migraine: Experience in 60 patients. Neurologia 2016;31:445-451.

15. Blumenfeld A, Ashkenazi A, Napchan U, et al. Expert consensus recommendations for the performance of peripheral nerve blocks for headaches-a narrative review. Headache 2013;53:437-446.

16. Tetzlaff JE. The pharmacology of local anesthetics. Anesthesiol Clin North Am 2000;18:217-233.

17. Dilli E, Halker R, Vargas B, et al. Occipital nerve block for the short-term preventive treatment of migraine: A randomized, double-blinded, placebocontrolled study. Cephalalgia 2015;35:959-968.

18. Kashipazha D, Nakhostin-Mortazavi A, Mohammadianinejad SE, et al. Preventive effect of greater occipital nerve block on severity and frequency of migraine headache. Glob J Health Sci 2014;6:209-213.

19. Inan LE, Inan N, Karadaş Ö, et al. Greater occipital nerve blockade for the treatment of chronic migraine: a randomized, multicenter, double-blind, and placebo-controlled study. Acta Neurol Scand 2015;132:270-277.

20. Ashkenazi A, Matro R, Shaw JW, Abbas MA, Silberstein SD. Greater occipital nerve block using local anaesthetics alone or with triamcinolone for transformed migraine: a randomised comparative study. J Neurol Neurosurg Psychiatry 2008;79:415-417.

21. Tepe N, Tertemiz OF. Comparison of greater occipital nerve and greater occipital nerve + supraorbital nerve block effect in chronic medication overuse headache. Turk J Med Sci 2021;51:1065-1070.

22. Blumenfeld A, Ashkenazi A, Grosberg B, et al. Patterns of use of peripheral nerve blocks and trigger point injections among headache practitioners in the USA: results of the American Headache Society Interventional Procedure Survey (AHS-IPS). Headache 2010;50:937-942. 